\title{
Innovation Transfer during the Warring States Period: Considering the Importance of Early
}

\section{China's Relationship with the Steppes}

\author{
Christine M. Havliček
}

\begin{abstract}
This paper focuses on the contact between pre-imperial China and the peoples living on the steppes in her vicinity. For all the obscurity that had been shrouding the steppe inhabitants throughout centuries of historical scholarship, archaeological discoveries during the past century attest to their highly developed culture and economy and, what is more, make obvious that they had been entertaining close relations with the Chinese from as early as the second millennium $B C E$. Following a line of scholarship which has set out to redefine the role of the steppes in world history on the basis of this new data, this paper aims to demonstrate certain aspects of the important role they played in the history of China. Several very impactful innovations diffused to early China through interactions with the steppes, influencing Chinese history to a major degree. The paper specifically concentrates on a timeframe surrounding the Warring States Period (c. 500221 BCE), during which a couple of key innovations can be shown to have been adopted from the steppes. Furthermore, it illustrates the impact of these innovations on historical developments within China, thereby reinforcing the argument that the role of the steppes in Chinese history was one of tremendous importance.
\end{abstract}

Keywords: China, Central Eurasia, Warring States Period, innovation transfer, steppes, nomads, cultural contact

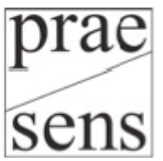

Havliček, Christine M. "Innovation Transfer during the Warring States Period: Considering the Importance of Early China's Relationship with the Steppes." In Vienna Journal of East Asian Studies, Volume 7, eds. Rudiger Frank, Ina Hein, Lukas Pokorny, and Agnes Schick-Chen. Vienna: Praesens Verlag, 2015, pp. 103-128. https://doi.org//10.2478/vjeas-2015-0004 


\section{Introduction}

In recent times, Central Eurasia as a geopolitical space has increasingly drawn the interest of researchers who have started to lift the fog of mystery the region and its history had been shrouded in. Likewise, the interactions between Central Eurasia and the great sedentary powers set on the outskirts of its periphery (such as ancient Rome, Greece, or China) have become an object of research which has, more often than not, completely overthrown notions about the Central Eurasian steppes and their inhabitants that had been ingrained in scholarly as well as public knowledge for centuries. In the tracks of this fundamental re-imagining and re-writing of the early history of the Central Eurasian steppes and its role in the history of the Eurasian continent as a whole, this paper examines the role of the steppes in Chinese history by looking at the historical significance of early China's interactions with the peoples of the steppes in its vicinity.

In accordance with the research done on the Eurasian steppes so far, the paper argues that China's early exchanges with the steppes were of tremendous importance to Chinese history. To demonstrate this, it looks at a couple of innovations that can be shown to have entered China from the steppes, focusing on a relatively short, yet disproportionately important part of Chinese history: the Warring States Period from about $500 \mathrm{BCE}$ to $221 \mathrm{BCE}$ was a time of major political turmoil, leading up to China's first unification under the rule of its first emperor Qín Shǐhuáng 秦始皇帝. The innovations that arrived in China during this period possessed high impact potential; both their adoption and their influence thus demonstrate the immense value of China's early interactions with the steppes for Chinese history.

\section{China's Relations with the Steppe Peoples in Former and More Re- cent Scholarship}

The topic of China's interactions with the inhabitants of the adjacent steppes has traditionally not been a popular one in Sinological scholarship; the underlying assumption always being that, before the 'official' opening of the Silk Road in the final centuries BCE, there had not been any notable interaction between the Chinese and people outside their cultural sphere. The dominating narrative was that Chinese civilisation had evolved in isolation, independent of any outside influences. Acknowledged connections to the Western world only started from the time of the 'official' opening of the Silk Road around 130 BCE. The official character of this linkage is usually related to historical records of Emperor Wǔ of the Hàn dynasty 漢 武帝 sending an emissary into the West on a quest for Heavenly Horses, an event which marks the beginning of China's endeavours to establish direct political and economic relations with states and peoples to its west (Kelekna 2009a: 146-148). 
But even with regard to the period after this crucial date, China's relations with the outside world had long been underrated, especially in the Sinological body of scholarship.

Centuries of research had been built upon historical records written by historiographers of peripheral empires, like Greece or China, and hence perpetuated a onesided image of the steppe inhabitants. Often these outside observers were politically biased and depicted the steppe dwellers as savage or uncivilised, reporting vicious attacks of mounted raiders (DiCosmo 1994: 1092). It did not help the cause when Western scholars started to introduce the notion of the 'barbarian' into translations of ancient Chinese documents, even though no such concept existed in the Chinese language (DiCosmo 2004: 95). In this way, the depreciatory view of the steppe inhabitants persisted, mostly unquestioned by both Eastern and Western researchers, throughout the centuries (Rogers 2012: 218). The role of the steppe peoples in early Eastern Eurasian history remained limited to their occasional appearance as the evil aggressor, extorting tribute and plundering from among the peaceful people of the great agricultural civilisations (for example, Sinor 1978; Barfield 2001: 235; Kradin 2002: 374).

This view has been challenged and revised dramatically in more recent times. Starting from the end of the nineteenth century, excavations brought to light an abundance of archaeological data from the steppe regions in present-day China and Mongolia which undermined earlier portrayals of their inhabitants by historical scholarship. Gradually, the image of the steppe peoples became more differentiated in the literature. Even though archaeology in this part of Central Eurasia is still in its infancy, the data that has been unearthed so far has served scholarship of recent decades well in pointing out the important role of the steppe peoples in history, and a number of scholars have worked hard to overturn the faulty notions of the 'barbarian' nature and the general insignificance of those peoples (see, for example, DiCosmo 1994, 1999, 2004; Kuzmina 1998, 2008; Beckwith 2009: 320-362).

From the archaeological record, it is now apparent that many different peoples lived in the vicinity of the Chinese from as early as the Shāng dynasty 商朝, the civilisation dominating the Yellow River valley from around 1600 to $1046 \mathrm{BCE}$. These steppe peoples had a culture clearly distinct from the early Chinese, in that their economy followed a different model of subsistence due to ecological reasons (DiCosmo 1999: 887). Even though their economy was typically built around oasis agriculture in the beginning, they always had a strong focus on animal husbandry. This cultural rift started to become more pronounced after a shift from agriculturebased to a more pastoral-based economy beginning in the late second millennium (DiCosmo 1999: 886). Around the start of the first millennium BCE, the fully mobile, horse-mounted form of pastoralism began to spread across the eastern steppes, from the Tarim Basin (in what today is the Uyghur Autonomous Province of Xīnjiāng 新疆維吾爾自治區 in the People's Republic of China) to the steppes of 
today's Mongolia and the Autonomous Province of Inner Mongolia, then at the verges of the Chinese civilisation (Kelekna 2009a: 65-66; Kuzmina 2008: 66, 112). In the beginning, various peoples with a mixed economy of farming and herding, such as the Róng 戎 and the Dí 狄, the Guřfāng 鬼方, the Xiănyŭn 獫狁, and many other ethnically and culturally non-Chinese peoples were living in a territory that was marginal to early China (DiCosmo 1999: 919-924). They formed a 'buffer zone' between the sedentary Chinese and the above mentioned all-out nomadic pastoralists, but were gradually swallowed up in the expansionist endeavours of the frontier states of Qín 秦, Zhào 趙, and Yān 燕 during the Warring States Period (Yáng 2009: 156). At this point, the Chinese are said to have come into direct contact with the fully nomadic peoples of the steppes for the first time (DiCosmo 1999: 892).

The first group of nomads to appear in Chinese historical records are called the Hú 胡, which was less of an ethnonym than a blanket word for nomads in general (Chen 1998: 777). They were either related to or were predecessors of the Xiōngnú 匈奴, who roamed the steppes to the northwest of China from the early Iron Age onwards (Beckwith 2009: 71). To the west lived the Wūsūn 乌孙, the Qiāng 㒸, and the Yuèzhī 月氏, or Tokharians (Beckwith 2009: 380-383), who occupied a territory stretching from the Tarim Basin to the Héxī corridor 河西走廊 (in the modern-day Gansu province) and were, for long stretches of history, the most powerful nomadic confederacy on the steppes to the west of China. Through their language they are connected to the city states in the Tarim Basin, with which they seem to have maintained close ties. The far western end of the Tarim Basin was inhabited by the Saka or Indo-Scythians, who were known to the Chinese as the Sài 塞 (Zhang 1999: 283). They had migrated there at the beginning of the first millennium BCE and were the ones who had brought the fully nomadic, horse-mounted pastoral lifestyle into the eastern steppes (DiCosmo 1999: 909). With the spread of this lifestyle, the early nomadic groups in the area eventually all became part of a certain cultural complex, the so-called 'Scythian continuum' (DiCosmo 1999: 891), which involved the presence of a certain assemblage of cultural signifiers - termed the 'Scythian triad' by DiCosmo (2004: 58) —including weaponry, horse-gear, and objects decorated in animal style. Another feature of Scythian culture was the use and dissemination of iron technology (Wagner 2008: 93) and swords with iron blades (DiCosmo 2004: $58)$.

In former writings, the pastoral economy of the nomads had often been portrayed as a reason for them to attack and raid settled agricultural communities. The view that they were poor and underdeveloped, lacked the nutrition and material wealth of the farming communities, and therefore were keen on obtaining these things by force, was a common judgement applied to nomads all over Central Eurasia (for example, Sinor 1981 and Kradin 2002: 373-374). However, neither the societal nor economic structures of the steppe dwelling nomads were that simple and uniform. Contrary to popular belief, nomadic society was self-sufficient, not least because 
they contained sedentary or semi-sedentary agriculturalist populations within their territories and communities and readily engaged in limited farming activities themselves whenever the ecological conditions and their migration cycles allowed for it (Sinor 1972: 172 and DiCosmo 1994: 1094). The average nomad at the time was generally better fed than a peasant in the adjoining Chinese feudal states and led a much easier life with more leisure time at his disposal (Beckwith 2009: 76). This, in turn, is one of the reasons why the arts and crafts were practiced widely and with great skill among the nomads, which together with the existence of large deposits of iron and copper in the Tarim Basin, enabled metallurgy to become an integral part of their material culture (Rolle 1980: 137 and Beckwith 2009: 9).

Their livestock was a major source of wealth which allowed for far greater surpluses than agriculture, which provided an economic basis for conducting trade on a considerable scale. The inherent mobility in the nomads' lifestyle meant that they covered long distances, and the trade relations they entertained with the sedentary parts of their society were carried over to other sedentary people they encountered. From the exchanges with these various foreign peoples they would not only obtain agricultural produce, but other material products which they could then bring along and trade off to others for great gain. For example, the great power and wealth of the Yuèzhī was based largely on successful trade and exchange with the Chinese (Benjamin 2007: 44); they were famous for their horses (Liu 2001: 273 and Benjamin 2007: 35) and known as suppliers of jade (Lin 1998: 482 and Benjamin 2007: 9).

All of this, again, runs contrary to the common image of nomads that had long dominated public opinion as well as academic scholarship - the needy, greedy nomad who had to pillage and plunder for a living (for example, Sinor 1978 and Torday 1997: 1). In general, the nomads did not need to go look for loot among their neighbours - trade relations were a lot more lucrative, held much smaller risks, meant less expense in terms of labour, and thus were a much more reliable and sustainable source of proceeds.

The term 'ecological border' (Christian 2000: 72-73) was coined to refer to the dividing lines between nomadic pastoralists and sedentary agriculturalists. These lines are of utmost importance when looking at the history of the Eurasian landmass: the stark difference between the respective economic systems of the pastoralists on the one and the agriculturalists on the other side generated a mutual need for exchange. In the trade of the respective economic produce, other goods such as luxury items, weapons, tools and more were readily exchanged, making the barter even more attractive. Less tangible things like new technologies, knowledge, ideas, and so on would also pass back and forth on these occasions. Because of this, ecological borders have been credited to be the reason for the unity of the entire Eurasian landmass: the vigorous exchanges they incited were the basic mechanism that allowed for the emergence of the vast trans-continental trade system that would later be known as the Silk Road. The sustention of this economy, while of course also 
relying on and needing the urbanites and farmers, depended in large part on the nomads and their mobility.

The following feature of the nomads' political order was another big incentive for trade. Most of the nomadic peoples belonging to the Scythian continuum were organised around the person of a single leader, who usually had a personal guard of warriors sworn to fight for him to their deaths - the comitatus (Beckwith 2009: 59). These warriors needed to be maintained with expensive gifts, and considering that a comitatus could sometimes swell to numbers of several thousands, the cost was often immense. This ensured that nomadic societies all over Eurasia were dependent on trade, as the very stability and safety of their communities relied on it (see Beckwith 2009: 26-27).

For a long time, the migratory and mercantile activities of the nomads were the major driving force and the sustaining factor behind the trade economy of Central Eurasia. Archaeological excavations have shown that parts of the system sustaining the continent-wide Silk Road economy were in place as early as 2000 BCE. Most of the nephrite jade used in pre-imperial China, for instance, was from Khotan, several thousand kilometres away in the western part of the Tarim Basin (Kuzmina 1998: 64; DiCosmo 1999: 902; Benjamin 2007: 34; Hill 2009: 615). At the same time, Chinese works of art, like lacquerware and bronze mirrors, have been found in areas that were unknown to the Chinese at the time of their transmission (see Rolle 1980: 41-44; Kuzmina 1998: 64; Kuzmina 2008: 3), attesting to trade contact long before the acknowledged date for the opening of the Silk Road.

The evidence of things having traversed the steppes at very early times is not limited to trade items. One of the earliest transmissions from steppe regions to the west was the domesticated horse, which arrived in China in the second millennium BCE (Beckwith 2009: 396). The war chariot arrived alongside the horse-a surprisingly complex piece of machinery that revolutionised early Chinese warfare (Shaughnessy 1988; Piggott 1992: 63; Anthony 1998: 94-95; DiCosmo 1999: 903). There are even claims that bronze metallurgy was introduced to China from the steppes, for which supportive archaeological data exists, and also the idea for writing, for which there is none so far (An Zhimin 1998: 60 and Sagart 1999: 196).

How close-knit and intense the contact between the early Chinese and the steppes must have been is not only illustrated by the trade connections and early transmissions of innovations, but also by linguistic evidence. There is one word in the Chinese language whose loanword status is unchallenged: $m i$ 蜜 ('honey') is widely accepted to have been borrowed from a Tokharian language, spoken by the Yuèzhī and some of the Tarim city states (Pulleyblank 1966: 10). In recent decades, many more loanwords from early Indo-European languages have been shown to exist (for example, Lin 1998 and Beckwith 2009: 402); for example, the word for 'horse' in all East Asian languages derives from an Indo-European root (Beckwith 2002: 130- 
133), which is consistent with the archaeological data showing its introduction from areas further west.

The entirety of the research summarised above demonstrates that China was never the isolated cultural island it had long been assumed to be. China was not only an extension of, but an integral part of the continent-encompassing Silk Road economy from very early on. From the earliest dawn of civilisation in the Yellow River Valley, interactions with the steppes took place; often through people migrating there. The Zhōu 周, for instance, were of steppe origin - probably Central Eurasians who crushed their predecessors, the Shāng, with the help of their chariots (Kelekna 2009a: 137-138; Kelekna 2009b: 17; Beckwith 2009: 45-46). Often, innovations would be carried to new areas by such migratory waves; there, they spread as newcomers directly taught the locals, who would then not only adopt innovations, but would often put their own cultural stamp on them as well (Roberts, Thornton and Pigott 2009: 1018). The complexity of many technologies ensured that they needed to be accompanied by all the relevant technological information and even by instruction in order for them to be adopted successfully (Barnard 1983: 249).

In view of this vast body of research, it is obvious that the interactions with the steppes were far from unimportant for Chinese history. In order to further demonstrate this, this paper will examine the impact of some ground-breaking innovations arriving through these interactions during the Warring States Period. In this period, rivalling Chinese states battled each other for greater political power, trying to fill the vacuum left by the disintegration of the Zhōu court. The political turmoil and social upheavals of the time make it especially interesting to look for outside influences. This period also happens to coincide with the arrival of a couple of particularly exciting innovations, whose adoption can be used to exemplify the nature of pre-imperial China's contact with the outside world and further illustrate the importance of this contact.

\section{Innovation Transfer during the Warring States Period}

\section{Iron Metallurgy}

The view that iron metallurgy was introduced to China from the West via the steppes is not commonly accepted and has long been a bone of contention in the literature (Barnard 1965, for example, argued against it). At the time of writing, however, the archaeological evidence is in favour of this hypothesis. A clear archaeological trail reflects the chronological spread of iron metallurgy across the steppes from West to East, departing from a centre in Western Asia (Roberts, Thornton and Pigott 2009: 1018). The technology in this scenario is wrought iron manufactured in 
bloomeries, which recent archaeological evidence shows to have been the first smelted iron that was used in China (Wagner 2008: 105). Iron smelting on the steppes and in the Chinese Northwest predates the earliest findings of cast iron in the south of China (DiCosmo 1999: 913); it seems that it inspired the invention of cast iron technology in southern China (the states Wú 吳 and Chǔ 楚) in the fifth century BCE (Wagner 2008: 106).

Many wrought iron artefacts, discovered fairly recently, strongly indicate an introduction to China from the outside (Táng 1993: 564 and Wagner 2008: 105). In the Tarim Basin, the earliest iron objects have been radiocarbon-dated to around the first millennium BCE (Kamberi 1998: 808 and DiCosmo 2004: 71); however, accounting for possible outliers, the beginning of the Iron Age in the area is dated to the eighth century BCE. From that century onwards, iron gradually gained popularity and it appears frequently in the eighth to sixth century Saka burials in the Xinjiang area and around the seventh century BCE in Mongolia and the north-eastern steppe, which shows a quick spread across the steppe zone. Iron findings from this time are also in evidence as far east as the Héxī corridor (Wagner 2008: 93). The fact that iron metallurgy was widespread on the steppes before it appeared on the Central Plains lends credibility to the theory of diffusion from West to East.

In China, man-made smelted iron first appears around the ninth to eighth centuries BCE. The very first items were found in Sānménxiá 三門峽, Hénán 河南一then the minor state of Guo 虢, ${ }^{1}$ which evidently had some ties to the steppes. They are dated to the ninth to eighth centuries BCE (Wagner 2008: 105). In Shănxī 陝西 further to the west, gold-iron artefacts including three short-swords and a few of the ring-pommelled knives that are considered to be a typical steppe design (Linduff 1995: 142 and DiCosmo 1999: 893) were found to have been made from smelted iron and dated to the seventh to sixth century BCE. Another bronze-iron short sword was excavated from a Qín tomb in Gānsù 甘肅 dated to the eighth or seventh century BCE; it is uncertain whether it was forged from smelted or meteoritic iron. All of these early iron pieces were found in north-western regions of the early Chinese cultural zone. Their very early and scattered appearance may, however, be an indication that they made their way to China as trade items. Iron metallurgy only started to gain popularity during the Warring States Period, with a clear increase in the numbers of artefacts discovered.

The chronological distribution of iron artefacts already strongly suggests an introduction of iron technology from the steppes. Another important point is presented by linguistics. The Chinese word for iron, tiě 鐵, first appears in the Y̌̌ Gòng 禹貢 (Tribute of $Y \breve{u}$ ), a text from the Shüjing 書經, which is likely to be a work from the late Warring States (Brooks and Brooks 2007). The estimated time of its appearance coincides with the first use of iron smelting technology in China. A comparative-

1 See glossary (p. 25). 
historical reconstruction is given by Beckwith (2005: 192): *hltèk $<* \chi$ lèk $<$ earlier * $\chi$ elèk; he notes that it is clearly the same word as the hypothetical Indo-European * ghelegh. It is therefore certain that the Chinese word for iron was adopted from outside influences. This not only lends another supporting clue to the view that iron technology was introduced to China, but also suggests speakers of an Indo-European language as the donors. The Sài are likely candidates for distributing iron metallurgy to the eastern steppes. Iron metallurgy is regarded as one of the signature parts of the Scythian culture (Wagner 2008: 97), and the earliest findings of iron in Xīnjiāng appear around the very time when the Sài migrated there. Their role in the transmission of iron metallurgy is certainly a topic of interest for further research.

\section{Horseback Riding}

Cavalry warfare happens to be one of the few innovations that are widely accepted to have been adoptions from the steppes; one of the reasons for this is that its adoption is specifically mentioned in Chinese historical records. The text that is often cited by scholars discussing the question of the origin of cavalry warfare in China is part of the Shĭji 史記, a historiography written and compiled by Hàn court historians Sīmă Tán 司馬談 and his son Sīmă Qiān 司馬遷, the latter of whom died around 145 BCE (Benjamin 2000: 108). The passage in question is part of the history of the Zhào kingdom, an anecdotal account of a debate about the adoption of Hú-style dress in 307 BCE (Shǐjì n.d.: juàn 43). This reform enforced by King Wǔ-líng of Zhào 趙武靈王 is often abbreviated to Hú fú qishè 胡服騎射 ('Hu clothing and mounted archery'). The question of whether or not to adopt mounted archery, however, is not discussed in the historical text. In spite of the fact that the establishment of a cavalry force must have been the main objective of this reform, which, as the king emphasises, is aimed at being able to oppose nomad incursions as well as Zhào's Chinese opponents (for example, Wáng and Dài 2005: 20 and Shěn 2010), the text passage is oddly focused on the seemingly minor issue of clothing.

This somehow incongruous documentation is linked to the problematic issue of author bias, which needs to be taken into account when reviewing any kind of ancient historical document. While ostensibly about the implementation of a reform as a whole, the text stresses the king's attempts to persuade his subjects of the necessity of change for the greater good of the country with the help of Confucian morals. This shows how Sīmă Qiān, a diligent scholar who often cited sources consisting of historiographical material from earlier dynasties or kingdoms, was using this account to get across a moral lesson, as he was an ardent supporter of Confucian and Daoist thought. In addition to this, Sīmă Qiān's sources were limited, partly due to the mass destruction of many documents under Qín Shǐhuáng, forcing 
the historian to supplement missing information with popular romance and legend (Watson 1993: 3-5).

A couple of other ancient texts are relevant to the question of when cavalry ar-

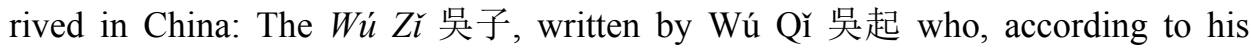
biography in the Shijji, lived between ca. 440 and 361 BCE, contains several mentions of cavalry (Sawyer 1993: 224). The Sün Ž̌ Bīngfă 孫子兵法, a text that is commonly ascribed to Sūn Wŭ 孫武, includes an explicit discussion of the 'ten advantages of using cavalry'. Both would point to cavalry appearing in China several decades before King Wǔ-líng's reform, which is what some scholars have argued in recent decades (Goodrich 1984: 304 and Ames and Lau 2003: 32). The issue is confounded by yet another problem shared by most ancient texts: the earliest surviving version of the Shiji dates to the fifth or sixth century CE (Watson 1993: 35), the latest copy of the $W u ́ z \check{\imath}$ stems from the Hàn dynasty (Sawyer 1993: 192), and the passage in the Sūn Ž̀ Bīngfă seems to have been falsely attributed to Sūn Wŭ and was actually part of the Sün Bìn Bīngfă 孫臏兵法 (Ames and Lau 2003: 33), the oldest extant version of which also dates to the Hàn dynasty. All of them therefore are written centuries after the originals.

Despite the pitfalls of historical records, it is commonly agreed that cavalry warfare was adopted by the Chinese from the steppe nomads roughly between 350 and $300 \mathrm{BCE}$. However, several clues indicate that the innovation was far more basic than even including a division for mounted combat into the Chinese armies; it is likely that horseback riding in general was not undertaken in China before the adoption of cavalry. Chariots were still widely in use in this period and were revered as status symbols; straddling the back of a horse, in contrast, would have seemed a lot less dignified. The above-mentioned passage from the Shǐji hints at this problem: the Zhào officials are reluctant to adopt nomad clothing which, in contrast to their dignitary robes, is suitable for riding, which lends some credibility to the notion that horse riding was not practiced in Zhào before that time, and the same restrictions were probably true for other states.

Apart from this, a clear archaeological chronology shows the gradual eastward spread of horseback riding from an origin somewhere on the Pontic-Caspian steppes (Anthony 2007: 221). It arrived in Xīnjiāng around the start of the first millennium $\mathrm{BCE}$, where it spread across the eastern steppes along with horse-mounted nomadism (Chen and Hiebert 1995: 285). It seems to have been practiced widely throughout the steppes adjacent to early China by the eighth century BCE (Kuzmina 1998: 82). The exact point in time when horseback riding started being practiced in China is, however, hard to prove archaeologically. While horses start showing up in burial sites entombed without their accompanying chariots after the adoption of riding, the transition was a gradual one, since the chariot continued to be used as a sign of power, wealth, and influence well through the Qín dynasty — as is illustrated by the chariots in Qín Shǐhuáng's tomb. There are no outside indicators on horse 
bones that could tell whether a horse was ridden or driven when alive. The only piece of horse tack that could identify a horse as a riding horse, the saddle, was at the time constructed from organic materials like wood, felt, and leather, which seldom survive to show up in archaeological excavations.

Artistic depictions of horse riding appear during the Warring States Period, but they are not dated very precisely. A lacquered box excavated at Chángshā 長沙, the capital of the state Chŭ 楚, and dated to the Warring States Period, depicts a person mounted on a horse that is outfitted with a bridle and several straps that could indicate the presence of a saddle or saddle pad. Another, an inlaid mirror, shows a mounted warrior attacking an animal with a short sword (Goodrich 1984: 282). It is not possible to assert, in this survey, whether these items were manufactured in China or imported. Yet no depictions of horseback riding have been found in China dated earlier than the Warring States Period.

In the case of riding for warfare purposes, most scholars agree that it started being practiced only around the beginning of the first millennium $\mathrm{BCE}$, around the same time hard metal bits appear (Bokovenko 2000: 304; Drews 2004: 71; Anthony 2007: 223). Unlike their predecessors made from wood, bone, or rope, these bits were impossible for the horse to chew through and thus, for the first time, they gave the riders reliable control over their mounts, which was indispensable for engaging in battle. In China, bronze bits do appear with greater frequency during the Eastern Zhōu dynasty, in particular in the north-western parts of early China (Liú and Zhū 1981 and Luòyángshì Wénwù Gōngzuòduì 2009a-b), which would strongly point to an introduction from the steppes. However, they seem to have been used even before the adoption of cavalry warfare, probably with chariot horses. Some pieces of the bronze bit do exhibit strong steppe influences and plainly point to some form of transmission from the steppe nomads (Jettmar 1971: 16). This is especially visible in the similarity of the S-shaped design of cheek-bars (Goodrich 1984: 295), whose function was to provide lateral pressure upon drawing the reins. The function of the S-shape is not entirely clear; the lower curve could have acted as an additional reinforcement (Sidnell 2006: 84) or might just have been a decorative element. In the latter case, the fact that it was nevertheless adopted would be all the more striking.

While the archaeological data is unfortunately too scarce to paint a coherent picture, it still corroborates the view that horseback riding was adopted by the Chinese from the steppe nomads during the Warring States Period. It does seem to have been introduced as a warfare method that had already been perfected by the nomads prior to the time of its transmission to the Chinese. The successful deployment of this method depended not only on the mastery of horseback riding, but included the use of weaponry specialised for the purpose. In these early times, the most effective weapon for horseback combat was the bow. Since self bows in use at the time were far too long to be shot from a sitting position (Miller, McEwen and Bergman 1986: 
182), mounted combat could only become effective with the invention of the recurve bow around the first millennium BCE (Anthony 2007: 223-224). Through a unique combination of material with a greater compressive or tensile strength than wood, like horn, antler, bone, and sinew, and a new shape with back-curving tips, this invention allowed for bows to be constructed considerably shorter without the usual accompanying loss in range and impact (Miller et al. 1986: 187). In combination, these two innovations first appear in the form of the Scythian bow around the beginning of the first millennium BCE (see Rolle 1980: 72-74).

It is important to note that the technique of shooting a bow from horseback represents a remarkably complex set of skills that needs to be mastered before it can be exercised effectively, which has been noted to take large amounts of time and effort (Bivar 1972: 283 and Bái 2006: 138-139). This complexity is another indication for its adoption from the steppes and also shows once more how close the interactions between the Chinese and the steppe peoples must have been at times. It is apparent that the transmission of these skills must have involved direct teaching by experts. In the beginning, this probably was achieved through nomads hired out as mercenaries among the Chinese, who acted not only as the mounted force per se, but as horsehandlers, breeding experts, and instructors. Interaction as close as this may have precipitated additional effects; for example, the Chinese word for riding, $q i$ 騎, first appears in texts dated to the Warring States Period, and starts to appear with increasing frequency from then on (Goodrich 1984: 281). The fact that it turns up so abruptly indicates that it was a loanword adopted along with this new activity; it is likely that other words related to horseback riding were adopted as well.

In summary it may be said that the unique combination of complex factors involved in the appearance of both horseback riding and iron metallurgy in China points to their foreign origin. What the adoption of both the technology and the language illustrates is that the relationship between early China and the steppes was never as one-dimensional as to be reduced to war and conquest, but consisted of a complex mixture of migration, employment, and trade. These interactions must have been quite intimate at times, in order for the innovations to be successfully adopted by the Chinese; the adoption of loanwords also attests to this. While the actual development of a technology was, or can be assumed to have been, a process as complex as the relations between various groups of people, a clear impact of steppe contacts on these innovations can be deciphered from the evidence.

\section{The Impact of the Innovations on Chinese History}

The innovations in question are of a ground-breaking nature not only in terms of origin, but also because of their impact on the events of the times. The everchanging borders during the Warring States Period do not make it easy to determine 
the innovations' impact on China, yet the very fact that political dynamics were so competitive makes analysis seem worthwhile. It can be said that the rivalry that characterised this period was an important motivator for innovation and may also explain why outside innovations were more eagerly adopted. The states on the Chinese periphery continually expanded their territories at the cost of the steppe peoples, a strategic move which was not so much directed at securing their flanks as at gaining access to resources to help them in their struggle against their Chinese rivals. Any advantage was sought with a fierce energy and in this sense the frontier states may have had certain advantages, resulting from their shared borders with the steppes, over their more centrally located counterparts.

While the innovations discussed in this paper were not, by default, of a military nature, they were first adopted for military purposes: horseback-riding does not make an appearance on the Central Plains before cavalry warfare, and most of the wrought iron items of the early epoch are swords and other weapons. During this period, warfare methods changed considerably. Whereas battles in earlier times were elite affairs fought between noblemen with chariots, the Warring States Period saw the advent of large infantry armies, often drafted from among the common people, who were pitched against each other in mass campaigns led by professional generals. Furthermore, cavalry warfare gained more and more importance on the Chinese battlefields, where it soon replaced the chariot by the third century BCE (Puett 1998: 706). A mounted warrior has some basic advantages over a foot soldier: the horse provides the rider with an elevated position from which to fight, as well as with greater speed and mass with which to attack. The unprecedented mobility of the horse-mounted units must have proved a vital strategic asset, which the professional generals of the period were well equipped to exploit to their benefit.

The early form of cavalry, which the Chinese adopted from the steppes, was light cavalry, i.e. only lightly armed and armoured and not employed in direct shock combat and massed charges, but in skirmishing and for other tasks such as scouting ahead, securing the flanks, defence during retreats, raiding, cutting off the enemy's supply lines, and so on (Lewis 1999: 624). A light cavalry force was able to deal quick, powerful blows to the enemy's flanks or rear, and could disrupt the enemy's formation by sending volleys of arrows from a distance and inspiring fear and confusion in surprise attacks. When engaged, a rider could also join mêlée combat with his secondary weapons, like the sword.

However, the effectiveness of the early Chinese cavalry divisions was dependent on the units of mounted archers being limited in size and being used as supplements to the main infantry only (Dien 1986: 37 and Twitchett and Loewe 1986: 25). For a functioning cavalry, suitable horses had to be bred or acquired and trained for warfare; the techniques of riding and simultaneously using an array of weaponry from horseback needed to be mastered by the rider (Creel 1965: 649). In the early times, shortly after the adoption of the cavalry warfare method, all of these factors 
represented a problem for the Chinese. The problem of securing a supply of quality horses is a recurring one in Chinese history. The lack of suitable pastures on the Central Plains and a general inexperience in the handling and breeding of horses are often mentioned in historical records; it is also well documented that the Chinese always had to import horses from the steppes to replenish and improve their limited stocks (Beckwith 1991: 185). Before and during the Warring States Period, this factor conditioned the distribution of chariots; they were elite status symbols owned by the nobility and other wealthy people. With the arrival of riding and cavalry warfare, a good warhorse similarly came to represent status. The complex skills necessary for training horses as well as successfully employing the new warfare technique of mounted archery would have been rare in the beginning. Of course, all of these problems would have been circumvented by the employment of nomad mercenaries; in this case, the nomads brought their own horses and weapons as well as relevant expertise and training. The practicality of this is reflected in the fact that horse-handlers seem to be almost exclusively depicted as non-Chinese in artwork (Creel 1965: 670).

Despite these limitations, cavalry divisions could have a decisive impact on the outcome of battles. While examples from ancient China are lacking, Greek cavalry divisions from around the same time (i.e. around the fifth to third centuries BCE) were similarly equipped with projectile weapons and supplementary swords and were only between five hundred and one thousand men strong. Even in limited numbers, their attacking power was still substantial (Spence 1993: 103, 120). Throughout history there are many examples of small bands of cavalry - often comitatus warriors - turning the tide of a battle (Beckwith 2009: 145-146). On this basis, having a division of cavalry would have been a powerful asset for any state's army; it would definitely have changed the course of battles by widening the array of strategic moves available, and the question of having or not having a cavalry unit, as well as the unit's numbers, quality of material, and training, would then have an impact on their outcome. Unfortunately, neither historical nor archaeological sources can reveal crucial information about whether the adoption of cavalry allowed certain states to gain a decisive advantage over others. Theories that Zhào directly profited from its adoption of cavalry warfare (for example, Creel 1965: 651) are backed up by inconclusive evidence. Still, the pure potential of this innovation for turning the tides of battles was considerable.

Looking at the possible impact of iron metallurgy from a modern perspective, the arrival of such a basic technology with massive historical importance must have been a decisive event; especially so in a high-stakes environment like the Warring States Period. Its advent has indeed been credited with contributing to major developments ranging from an increase in agricultural production, which in turn caused large-scale population growth (Twitchett and Loewe 1986: 578), to causing the collapse of the feudal system (Ľ and Zhèng 1998) and contributing to Qín's success 
at the end of the Warring States Period by providing it with iron swords (Keightley 1976: 32).

Yet, from the first appearance of iron in China it took a couple of centuries to become popularised. At the time, bronze metallurgy had reached its apex concerning quality, versatility, and sophistication of production techniques, and as a result bronze weaponry, bronze tools, and bronze decorations were omnipresent. The early wrought iron weapons would have compared poorly to their bronze counterparts. Production in the early bloomeries usually resulted in wrought iron with a very low carbon content, which would be soft and liable to bend (Wagner 1996: 103). Cast iron, by contrast, would have been entirely useless for the production of weaponry because of its extreme brittleness. It took the development of new techniques like annealing, quench-hardening, and production of steel through the carburisation of iron blooms for iron to become a better material for weapons than bronze was (He 1983: 396). Only after the invention of these techniques during the later Warring States Period did bronze weapons gradually go out of use (Wagner 1996: 103). The reduced brittleness of wrought iron did give it one major advantage over bronze in the production of weapons: longer weapons could be made from it without the increased risk of it breaking during battle. Naturally, greater length increases the weapon's reach and thus gives its wielder the edge over an opponent with a shorter bronze sword (Wagner 1996: 197).

The question of whether specific states could have profited from their use of iron metallurgy, or more specifically iron weapons, has been discussed before. In 1951, Sekino Takeshi (cited in Keightley 1976: 31) offered the hypothesis that Qín at least partially owed its eventual victory to its successful implementation of iron technology, i.e., to its armies being equipped with wrought iron swords superior to the bronze swords of the other states. However, this has been disproved due to the small numbers found in excavations of both the weapon itself as well as smithy implements necessary to produce them. The massive numbers of swords Qín would have needed to equip its soldiers simply did not exist. While mass-production using malleable cast iron would have been possible at the end of the period, when technology had progressed to the point that the brittleness of cast iron no longer posed an insurmountable problem (Barnard 1978: 64 and Wagner 1996), the lack of iron swords in archaeological sites still speaks volumes. Instead of the sword being massproduced for the large armies of the time, it is likely that only officers and cavalry carried them in the Warring States Period (Barnard 1978: 63). Iron swords, as well as iron implements in general, remained relatively rare and therefore precious items throughout the Warring States Period, much like horseback riding and owning a horse seem to have been; it is possible that the warriors mounted on horses were the same ones that wielded the swords.

Although the massive numbers of iron swords that Qín would have needed for its conquests probably never existed, it has been noted that the technical background 
necessary for the manufacturing of iron swords is visible in the archaeological data for Qín at a time when no such background can be detected for Chǔ. Iron swords appear to have been used in Chǔ only after Qín's conquest in 278 BCE (Wagner 1996: 199). In this single instance, iron weaponry may actually have presented an advantage for one state in particular. By the early decades of the third century BCE, iron metallurgy had come into relatively widespread use throughout China, and the subsequent conquests cannot be explained that way anymore. Even though the frontier states Qín, Yān, and Zhào can be shown to have had earlier access to the new technology than the more central regions, their conquests were probably not specifically attributable to their use of iron weaponry.

As mentioned above, it is likely that both horseback riding as a method of warfare and iron weaponry may have been part of the same innovation package that arrived in the eastern steppes with the Sài, and were therefore connected, even though they may have arrived in China at different times due to the varying needs of the Chinese. Their impact on the outcomes of battles at the time was limited by the same factors: the rarity of both necessary knowledge and materials led to them being rare and precious status symbols owned by a small elite.

However, while the arrival of both horseback riding and iron smelting seem to have been linked to warfare in the first place, their impact was not limited to it at all. The advent of horseback riding can be assumed to have been quite revolutionary in a much more general way than cavalry. It represented a big step forward in terms of human mobility; persons and small goods could be transported both over longer distances and noticeably faster (Kelekna 2009a: 65). The advent of horseback riding can also be supposed to have represented a breakthrough in the transmission of information, permitting its delivery in unprecedentedly short time which, in turn, would have facilitated the establishment of an efficient information network. The continuous wars of the period had direct effects on the infrastructure at the time, as it became increasingly important to have a network of roads to move all those massive armies quickly and efficiently. These newly-built roads already improved communication, but only the advent of horseback riding made them the high-speed information arteries they were intended to be. The establishment of the first postal system in early China has also been dated to the Warring States Period; it worked through a network of postal stations, where a messenger on horse could rest and change horse quickly. Later, during the Hàn dynasty, this system would be extended all the way to Xīnjiāng (Ān 2006: 275). Overall, the arrival of horseback riding was a great step forward in terms of the speed in which information, people, or items could travel across China.

Aside from these obvious advantages, the development of an effective system of information transmission had some other noteworthy consequences. After the constant wars of the Spring and Autumn and early Warring States periods had severely weakened the feudal system, bureaucratic administration budded in most of the 
Chinese states, as more efficient forms of administration were needed for the successful future management of larger armies (Kiser and Yong 2003: 512). One of the necessary preconditions for a functioning bureaucracy is an effective system of communication; establishing 'technologies of control' (communications, transportation, and record-keeping) was essential in attaining the 'monitoring capacity' needed (Kiser and Yong 2003: 515). For transportation as well as communication, horseback riding represented a great improvement and may be seen as one of the big factors that helped propel ancient China into the age of bureaucracy. The most striking example for this is the state of Qín. It had a large and well-built network of roads and was situated in close vicinity to the steppe and its horses. At the same time it happened to be the state with the largest bureaucratic administration; although even Qín was only partly bureaucratised, its administrative innovations were of such a revolutionary nature that they outlasted the dynasty by more than two millennia (Kiser and Yong 2003: 512).

Iron smelting technology also had an advantage beyond the production of weaponry. Its one clear benefit over bronze was an economic one. Copper and tin deposits in China were sufficient to develop a thriving bronze culture, but iron was in much greater supply and often available in an easily accessible form; it therefore required less economic effort to acquire and use. Its readier availability was one of the first incentives to develop iron technology during the heydays of bronze and may have played a large role in its eventual triumph over bronze (Rostoker et al. 1983: 196-197 and Golas 1999: 151).

While the white cast iron produced in the beginning was not suited for the production of weapons its extreme hardness in addition to its low cost made it perfect for the mass production of tools for agriculture and crafts. This made iron superior to bronze in economic terms, even before the invention of malleable cast iron (Wagner 2008: 147), and iron went on to replace bronze in tool-making much more quickly than in weapon-making. The mass production of agricultural tools is credited to have induced a rise in agricultural production during the Spring and Autumn and Warring States periods (Hsu 1999: 578). Seen in this light, the innovation of iron metallurgy was decisive indeed. Certainly, as a new technology, iron metallurgy made an impression and would go on to transform the weaponry in China over time. In the beginning, however, it did not make as big a difference in military strength as it had an impact on the economic strength of a state due to the correlation between massproduced iron tools and the increase in agricultural production. Any state that was able to implement this technology to its advantage would profit from it to a major degree.

What is visible on the Central Plains after the advent of iron metallurgy is that the power of the Zhōu court withers while the feudal lords gather power towards themselves. When iron metallurgy slowly gains popularity, the feudal system itself starts to unravel as a few states gather enough power to overtake their rivals and set 
up larger and more centralised kingdoms. It has been suggested that the advent of iron metallurgy was responsible for the demise of the feudal system, based on the argument that iron tools increased agricultural production to an extent that made the well-field system, on which the Zhōu feudal system relied, redundant (Lǐ and Zhèng 1998). Since the mass production of iron requires a large amount of organisation, from the supply of fuel to the procurement of the raw material to the assembly of a sufficient work force, it is possible that the arrival of mass-produced tools assisted in the downfall of small fiefdoms that were not able to keep up with the demands of production. Bigger and more centralised states would unquestionably have had an edge in that respect and soon leave their smaller rivals behind.

A few states can be seen to have grown considerably after the downfall of the Zhōu court, and the frontier states Qín, Zhào, and Yān are among them, probably not least because they were able to profit from their vicinity to the steppes. Not only would they have adopted useful innovations earlier; continuous innovation, in general, is said to be easier with a constant flow of outside stimulus (Curtin 1984: 1). To which exact degree they profited from their shared borders with steppes, is hard to say at this point; but they turned out to be successful where many other states were overtaken.

\section{Conclusion}

Despite the limitations of historical records and at times slender archaeological evidence, the case for the adoption of the innovations presented in this paper is surprisingly conclusive. Both horseback riding and iron technology are very likely to have been steppe contributions, adopted by the Chinese Warring States for use in waging war against their opponents. The nature of the innovations demonstrates the complexity of the interactions between the early Chinese and their steppe neighbours. While the impact of these innovations on the outcome of actual battles turned out to be restricted by certain factors, the ramifications for the developments during the Warring States Period and for Chinese history in general were tremendous. Both the radical way in which horseback riding managed to revolutionise transportation and the transmission of information, and the economic impact of iron metallurgy may have been factors in the development of the Chinese cultural zone from a cluster of feudal states over competing kingdoms towards one large centralised empire.

All of these observations serve to illustrate that the interactions between early China and the steppe peoples were a lot more significant than widely believed to this day. The vital role of trans-ecological trade for Eurasian history, even world history, has been noted by scholars before; this study has shown that its role in forming Chinese culture and civilisation likewise cannot be disregarded. Even in a timeframe 
as narrow as the few hundred years of the Warring States Period, the impact of China's steppe relations was remarkable. It is evident that China's relationship with the steppes must be considered an important factor in Chinese history that deserves to be elevated to a more important position within historical research. 


\section{REFERENCES}

Ames, Roger T. and Dim Cheuk Lau. Sun Bin: The Art of Warfare. A Translation of the Classic Chinese Work of Philosophy and Strategy. Albany: State University of New York Press, 2003

An, Zhimin. "Cultural Complexes of the Bronze Age in the Tarim Basin and Surrounding Areas." In The Bronze Age and Early Iron Age Peoples of Eastern Central Asia, edited by Victor H. Mair. Washington D.C.: Institute of the Study of Man, 1998, pp. 45-62

Ān, Zhōngyì 安忠义. “Hàndài de yăngmǎ yèjí duì măzhǒng de găiliáng” 汉代的养马业及对马种 的改良 [The Horse-Breeding Trade in the Hàn Dynasty and Improvements in Horse Breeds]”. In Nóngyè kăogǔ 农业考古 [Agricultural Archaeology], 4, 2006, pp. 273-280

Anthony, David W. "The Opening of the Eurasian Steppe at 2000 BCE." In The Bronze Age \& Early Iron Age Peoples of Eastern Central Asia, edited by Victor H. Mair. Washington D.C.: Institute of the Study of Man, 1998, pp. 94-113

Anthony, David W. The Horse, the Wheel, and Language: How Bronze-Age Riders from the Eurasian Steppes Shaped the Modern World. Princeton: Princeton University Press, 2007

Bái, Guóhóng 白国红. “Guānyú Zhōngguó dìȳ̄ zhī jiànzhì qíbīng de shǐxué sīkăo” 关于中国第一 支建制骑兵的史学思考 [A Few Historiographical Thoughts Regarding the Establishment of the First Cavalry in China]. In Shèhuì kexxué lùntán 社会科学论坛 [Social Science Tribune], 3/2 (下), 2006, pp. 138-141

Barfield, Thomas. "Steppe Empires, China, and the Silk Route: Nomads as a Force in International Trade and Politics." In Nomads in the Sedentary World, edited by Anatoly M. Khazanov and Andre Wink. London: Routledge, 2001, pp. 234-249

Barnard, Noel. "The Special Character of Metallurgy in Ancient China." In Application of Science in Examination of Works of Art. Proceedings of the Seminar: September 7-16, 1965, Conducted by the Research Laboratory, Museum of Fine Arts, Boston, Massachusetts, 1965, pp. 184-205

Barnard, Noel. "Did the Swords Exist?” In Early China, 4, 1978, pp. 60-65

Barnard, Noel. "Further Evidence to Support the Hypothesis of Indigenous Origins of Metallurgy in Ancient China." In The Origins of Chinese Civilization, edited by David N. Keightley. Berkely, Los Angeles and London: University of California Press, 1983, pp. 237-277

Beckwith, Christopher. "The Impact of the Horse and Silk Trade on the Economies of T'ang China and the Uighur Empire: On the Importance of International Commerce in the Early Middle Ages." In Journal of the Economic and Social History of the Orient, 34, 1991, pp. 183-198

Beckwith, Christopher. Medieval Tibeto-Burman Languages. Leiden: Brill, 2002

Beckwith, Christopher. Medieval Tibeto-Burman Languages II. Leiden: Brill, 2005

Beckwith, Christopher. Empires of the Silk Road: A History of Central Eurasia from the Bronze Age to the Present. Princeton: Princeton University Press, 2009

Benjamin, Craig. The Yuezhi: Origin, Migration and the Conquest of Northern Bactria. Washington D.C.: Brepols Publishers, 2007

Benjamin, Craig. "The Yuezhi and Their Neighbours: Evidence for the Yuezhi in the Chinese Sources C. 220-C. 25 BCE.” In Realms of the Silk Roads: Ancient and Modern, edited by David Christian and Craig Benjamin. Washington D.C.: Brepols Publishers, 2000, pp. 105-159

Bivar, Adrian David Hugh. "Cavalry Equipment and Tactics on the Euphrates Frontier." In Dumbarton Oaks Papers, 26, 1972, pp. 271-291

Bokovenko, Nikolay A. "The Origins of Horse Riding and the Development of Ancient Central Asian Nomadic Riding Harnesses.” In Kurgans, Ritual Sites, and Settlements: Eurasian Bronze and Iron Age, edited by Jeannine Davis-Kimball. Oxford: Archaeopress, 2000, pp. 304-307 
Brooks, E. Bruce and A. Taeko Brooks. "An Overview of Selected Classical Chinese Texts." 2007, University of Massachusetts Amherst website, http://www.umass.edu/wsp/sinology/ overview.html, accessed February 2014

Chen Chien-wen. "Further Studies on the Racial, Cultural, and Ethnic Affinities of the Yuezhi." In The Bronze Age and Early Iron Age Peoples of Eastern Central Asia, edited by Victor H. Mair. Washington D.C.: Institute of the Study of Man, 1998, pp. 767-784

Chen, Kwang-tzuu and Fredrik T. Hiebert. "The Late Prehistory of Xinjiang in Relation to Its Neighbors." In Journal of World Prehistory, 9/2, 1995, pp. 243-300

Christian, David. "Silk Roads or Steppe Roads? The Silk Roads in World History." In Journal of World History, 11/1, 2000, pp. 1-26

Creel, Herrlee G. "The Role of the Horse in Chinese History." In The American Historical Review, 70/3, 1965, pp. 647-672

Curtin, Philip D. Cross-Cultural Trade in World History. Cambridge: Cambridge University Press, 1984

DiCosmo, Nicola. "Ancient Inner Asian Nomads: Their Economic Basis and Its Significance in Chinese History.” In The Journal of Asian Studies, 53/4, 1994, pp. 1092-1126

DiCosmo, Nicola. "The Northern Frontier in Pre-Imperial China." In The Cambridge History of Ancient China: From the Origins of Civilization to 221 B.C., edited by Michael Loewe and Edward L. Shaughnessy. Cambridge: Cambridge University Press, 1999, pp. 885-966

DiCosmo, Nicola. Ancient China and Its Enemies: The Rise of Nomadic Power in East Asian History. Cambridge: Cambridge University Press, 2004

Dien, Albert E. "The Stirrup and Its Effect on Chinese Military History." In Ars Orientalis, 16, 1986, pp. 33-56

Drews, Robert. Early Riders: The Beginnings of Mounted Warfare in Asia and Europe. New York: Routledge, 2004

Golas, Peter J. Science and Civilisation in China, Vol. 5: Chemistry and Chemical Technology. Part XIII: Mining, edited by Joseph Needham. Cambridge: Cambridge University Press, 1999

Goodrich, Chauncey S. "Riding Astride and the Saddle in Ancient China." In Harvard Journal of Asiatic Studies, 44/2, 1984, pp. 279-306

He, Tangkun. "Metallurgy." In Ancient China's Technology and Science, edited by Chinese Academy of Sciences Institute of the History of Natural Sciences. First Edition. Beijing: Foreign Languages Press, 1983, pp. 392-403

Hill, John E. Through the Jade Gate to Rome: A Study of the Silk Routes during the Later Han Dynasty 1st to 2nd Centuries CE; an Annotated Translation of the Chronicle on the 'Western Regions' from the Hou Hanshu. Charleston: BookSurge, 2009

Hsu, Cho-yun. "The Spring and Autumn Period." In The Cambridge History of Ancient China: From the Origins of Civilization to 221 B.C., edited by Michael Loewe and Edward L. Shaughnessy. Cambridge: Cambridge University Press, 1999, pp. 545-586

Jettmar, Karl. "Metallurgy in the Early Steppes.” In Artibus Asiae, 33/(1/2), 1971, pp. 5-16

Kamberi, Dolkun. "Discovery of the Täklimakanian Civilization during a Century of Tarim Archeological Exploration (ca. 1886-1996)." In The Bronze Age and Early Iron Age Peoples of Eastern Central Asia, edited by Victor H. Mair. Washington D.C.: Institute of the Study of Man, 1998, pp. 785-811

Keightley, David N. "Where Have All the Swords Gone? Reflections on the Unification of China." In Early China, 2, 1976, pp. 31-34

Kelekna, Pita. The Horse in Human History. Cambridge: Cambridge University Press, 2009a

Kelekna, Pita. "The Politico-Economic Impact of the Horse on Old World Cultures: An Overview.” In Sino-Platonic Papers, 190, 2009b 
Kiser, Edgar, and Yong Cai. "War and Bureaucratization in Qin China: Exploring an Anomalous Case.” In American Sociological Review, 68/4, 2003, pp. 511-539

Kradin, Nikolay N. "Nomadism, Evolution and World-Systems: Pastoral Societies in Theories of Historical Development.” In Journal of World-systems Research, 8/3, 2002, pp. 368-388

Kuzmina, Elena E. "Cultural Connections of the Tarim Basin People and Pastoralists of the Asian Steppes in the Bronze Age." In The Bronze Age and Early Iron Age Peoples of Eastern Central Asia, edited by Victor H. Mair. Washington D.C.: Institute of the Study of Man, 1998, pp. 63-93

Kuzmina, Elena E. and Victor H. Mair. The Prehistory of the Silk Road. Philadelphia: University of Pennsylvania Press, 2008

Lewis, Mark Edward. "Warring States Political History." In The Cambridge History of Ancient China: From the Origins of Civilization to 221 B.C., edited by Michael Loewe and Edward L. Shaughnessy. Cambridge: Cambridge University Press, 1999, pp. 587-650

Lǔ, Bō 李波 and Zhèng Y̌̌ng 郑颖. Zhōnghuá wŭqiān nián 中华五千年 [5000 Years of Chinese History]. Hohhot: Nèi Měnggŭ rénmín chūbănshè 内蒙古人民出版社 [Inner Mongolian People's Publishing Corp.], 1998

Lin, Meicun. "Qilian and Kunlun - The Earliest Tokharian Loanwords in Ancient Chinese." In The Bronze Age and Early Iron Age Peoples of Eastern Central Asia, edited by Victor H. Mair. Washington D.C.: Institute of the Study of Man, 1998, pp. 476-482

Linduff, Katherine. "Zhukaigou, Steppe Culture and the Rise of Chinese Civilization." In Antiquity, 69, 1995, pp. 133-145

Liú, Dézhēn 刘得桢 and Zhū Jiàntáng 朱建唐. “Gānsù Língtái Xiàn Jĩngjiāzhuāng Chūnqiū mù” 甘肃灵台县景家庄春秋墓 [A Spring and Autumn Tomb in Jingjiāzhuāng, Língtái County, Gānsù]. In Kăogŭ 考古 [Archaeology], 4, 1981, pp. 298-301

Liu, Xinru. "Migration and Settlement of the Yuezhi-Kushan: Interaction and Interdependence of Nomadic and Sedentary Societies." In Journal of World History, 12/2, 2001, pp. 261-292

Luòyáng Shì Wénwù Gōngzuòduì 洛阳市文物工作队. "Hénán Luòyáng Shì Rùnyáng Guăngchăng C1M9950 hào Dōng Zhōu mùzàng de fājué” 河南洛阳市润阳广场 C1M9950 号东周 墓葬的发掘 [The Excavation of the No. C1M9950 Eastern Zhōu Burial in Rùnyáng Square in Luòyáng, Hénán]. In Kăogǔ 考古 [Archaeology], 12, 2009a, pp. 18-31

Luòyáng Shì Wénwù Gōngzuòduì 洛阳市文物工作队. “Luòyáng Wángchéng Guăngchăng Zhànguó mù (Xī Qū M37) fājué jiănbào” 洛阳王城广场战国墓 (西区 M37) 发掘简报 [A Short Report of the Excavation of a Warring States Tomb (Western Area M37) on Wángchéng Square in Luòyáng]. In Wénwù 文物 [Cultural Relics], 11, 2009b, pp. 22-29

Miller, Roger, Ellen McEwen, and C. Bergman. "Experimental Approaches to Ancient Near Eastern Archery.” In World Archaeology, 18/2, 1986, pp. 178-195

Piggott, Stuart. Wagon, Chariot and Carriage: Symbol and Status in the History of Transport. London: Thames and Hudson, 1992

Puett, Michael. "China in Early Eurasian History: A Brief Review of Recent Scholarship on the Issue." In Bronze Age and Early Iron Age Peoples of Eastern Central Asia, edited by Victor H. Mair. Washington D.C.: Institute of the Study of Man. 1998, pp. 699-715

Pulleyblank, Edwin G. "Chinese and Indo-Europeans." In Journal of the Royal Asiatic Society of Great Britain and Ireland, 1/2, 1966, pp. 9-39

Roberts, Benjamin W. Christopher P. Thornton, and Vincent C. Pigott. "Development of Metallurgy in Eurasia." In Antiquity, 83/322, 2009, pp. 1012-1022

Rogers, J. Daniel. "Inner Asian States and Empires: Theories and Synthesis." In Journal of Archaeological Research, 20/3, 2012, pp. 205-256 
Rolle, Renate. Die Welt der Skythen. Stutenmelker und Pferdebogner: Ein Reitervolk in Neuer Sicht. Luzern: C. J. Bucher, 1980

Rostoker, W. et al. "Casting Farm Implements, Comparable Tools and Hardware in Ancient China." In World Archaeology, 15/2, 1983, pp. 196-210

Sagart, Laurent. The Roots of Old Chinese. Amsterdam: Benjamins, 1999

Sawyer, Ralph D. The Seven Military Classics of Ancient China. Boulder: Westview Press, 1993

Shaughnessy, Edward L. "Historical Perspectives on the Introduction of the Chariot into China." In Harvard Journal of Asiatic Studies, 48.1, 1988, pp. 189-237

Shěn, Yǒng 沈勇. “Zhōngguó gǔdài zhōngyuán wángcháo duìkàng yóumù mínzú qíbīng de zhànshù - 中国古代中原王朝对抗游牧民族骑兵的战术 [Military Tactics of the Ancient Central Plains Kingdoms to Oppose the Cavalry of the Nomad People]." In Wénxué jiè 文学界 [World of Literature], 下旬 008, 2010, p. 205

Shĭji 史記 [Records of the Grand Historian]. (Băinàběn èrshísì shǐ 縮印百衲本二十四史 [Collection of Twenty-Four Histories] No. 1.) Shànghăi: Shāngwù Yìnshūguăn 商務印書館 [Commercial Press], n.d.

Sidnell, Philip. Warhorse: Cavalry in Ancient Warfare. London: Hambledon Continuum, 2006

Sinor, Denis. "Horse and Pasture in Inner Asian History." In Oriens Extremus, 19, 1972, pp. 171183

Sinor, Denis. "The Greed of the Northern Barbarian." In Aspects of Altaic Civilization II, Proceedings of the XVIII PIAC, Bloomington, June 29-July 5, 1975. Bloomington: Indiana, 1978, pp. $171-182$

Sinor, Denis. “The Inner Asian Warriors.” In Journal of the American Oriental Society, 101/2, 1981, pp. 133-144

Spence, Iain G. The Cavalry of Classical Greece: A Social and Military History with Particular Reference to Athens. Oxford: Clarendon Press, 1993

Táng, Jìgēn 唐际根. “Zhōngguó yětiěshù de qǐyuán wèntí” 中国冶铁术的起源问题 [The Problem of the Origin of Iron Technology in China]. In Kăoǧ̌ 考古 [Archaeology], 6, 1993, pp. 556565

Torday, Laszlo. Mounted Archers: The Beginnings of Central Asian History. Durham: The Durham Academic Press, 1997

Twitchett, Denis and Michael Loewe, eds. "The State and Empire of Ch'in." In The Cambridge History of China, Vol. 1: The Ch'in and Han Empires, 221 BC-AD 220. Cambridge: Cambridge University Press, 1986, pp. 20-102

Wagner, Donald B. Iron and Steel in Ancient China. Leiden: Brill, 1996

Wagner, Donald B. Science and Civilisation in China, Vol. 5: Chemistry and Chemical Technology, Part 11, Ferrous Metallurgy. Cambridge: Cambridge University Press, 2008

Wáng, Jùnjí 王俊奇 and Dài Xīnlín 戴新林. “Zhōngguó gǔdài de măbèi wǔyì jíqí wǔshù tèdiăn" 中国古代的马背武艺及其武术特点 [Ancient Chinese Horseback Martial Arts and Their Special Characteristics]. In Bóji: Wǔshù kēxué 搏击: 武术科学 [Wrestling: Martial Arts Research], 2, 2005, pp. 20-22

Watson, Burton. Records of the Grand Historian: Han Dynasty. New York City: Columbia University Press, 1993

Yáng, Jiànhuá 杨建华. “Zhōngguó běifāng Dōng Zhōu shíqī liăng zhǒng wénhuà yícún biànxījiānlùn Róng-Dí yǔ Hú de guānxi” 中国北方东周时期两种文化遗存辨析一兼论戎狄与胡的 关系 [Analysis of Two Types of Cultural Remains in the Chinese North of the Eastern Zhōu Period - Concurrently Discussing the Relationship of the Róng-Dí with the Hú]. In Kăogǔ xuébào 考古学报 [Journal of Archaeology], 2, 2009, pp. 155-183 
Zhang, Guang-da. "The City-States of the Tarim Basin." In History of Civilizations of Central Asia: The Crossroads of Civilizations, AD 250 to 750, edited by Ahmad Hasan Dani. Delhi: Motilal Banarsidass Publishers, 1999, pp. 281-301 


\section{GLOSSARY}

\begin{tabular}{|c|c|c|}
\hline Chángshā & 長沙 & $\begin{array}{l}\text { the capital of the state Chǔ during the } \\
\text { Warring States Period }\end{array}$ \\
\hline Chǔ & 楚 & $\begin{array}{l}\text { one of the Warring States, situated in the } \\
\text { South }\end{array}$ \\
\hline Dí & 狄 & $\begin{array}{l}\text { one of the semi-sedentary peoples living in } \\
\text { close vicinity to the early Chinese }\end{array}$ \\
\hline Gānsù & 甘肅 & a province located in North-western China \\
\hline Guǐfāng & 鬼方 & $\begin{array}{l}\text { one of the semi-sedentary peoples living in } \\
\text { close vicinity to the early Chinese }\end{array}$ \\
\hline Guó & 虢 & $\begin{array}{l}\text { a minor state of the Spring and Autumn } \\
\text { Period, located in today's Henan province }\end{array}$ \\
\hline Hàn cháo & 漢朝 & the Hàn dynasty, 206 BCE-220 CE \\
\hline Hénán & 河南 & a province located in central China \\
\hline Héxī Zǒuláng & 河西走廊 & $\begin{array}{l}\text { the Héxī corridor, also known as Gānsù } \\
\text { corridor, characterised by a series of oases } \\
\text { between the Gobi desert in the north and the } \\
\text { Qilian mountains in the South that con- } \\
\text { nected the Yellow River valley with the } \\
\text { Tarim Basin. }\end{array}$ \\
\hline Hú & 胡 & $\begin{array}{l}\text { a blanket term for 'nomads' used by the } \\
\text { early Chinese }\end{array}$ \\
\hline Húfú qíshè & 胡服騎射 & $\begin{array}{l}\text { 'Hu clothing and mounted archery', a } \\
\text { reform by the King of Zhào mentioned in } \\
\text { the Shíji }\end{array}$ \\
\hline mì & 蜜 & 'honey' \\
\hline qí & 騎 & 'to ride (astride)' \\
\hline Qiāng & 㒸 & $\begin{array}{l}\text { one of the nomadic peoples living in the } \\
\text { steppes to the west of early China }\end{array}$ \\
\hline Qín & 秦 & $\begin{array}{l}\text { the western-most of the Warring States, at } \\
\text { the borders to the steppes }\end{array}$ \\
\hline Qín Shǐhuáng-dì & 秦始皇帝 & China's first emperor (260-210 BCE) \\
\hline Róng & 戎 & $\begin{array}{l}\text { one of the semi-sedentary peoples living in } \\
\text { close vicinity to the early Chinese }\end{array}$ \\
\hline Sài & 塞 & $\begin{array}{l}\text { also called Saka, Indo-Scythians; a nomadic } \\
\text { people living in the south and west of the } \\
\text { Tarim Basin and the Altai mountains }\end{array}$ \\
\hline Sānménxiá & 三門峽 & a city in Hénán province \\
\hline Shănxī & 陝西 & a province located in western central China \\
\hline Shāng cháo & 商朝 & the Shāng dynasty, c. 1600 BCE-1046 BCE \\
\hline Shǐji & 史記 & $\begin{array}{l}\text { Records of the Grand Historian, a historiog- } \\
\text { raphy from the Hàn dynasty }\end{array}$ \\
\hline Shüjīng & 書經 & $\begin{array}{l}\text { The Book of Documents, a late Warring } \\
\text { States work }\end{array}$ \\
\hline Sīmǎ Qiān & 司馬遷 & $\begin{array}{l}\text { Hàn court historian, author of the Shijì, } \\
\dagger 145 \text { BCE }\end{array}$ \\
\hline
\end{tabular}


Sīmă Tán

Sūn Bìn Bīngfă

Sūn Wǔ

Sūn Zì Bīngfă

tiě

Wú

Wǔ-dì

Wǔ-líng of Zhào

Wūsūn

Wú Q⿺̌̀

Wú Zì

Xiănyǔn

Xīnjiāng Wéiwú'ěr zìzhìqū

Xiōngnú

Yān

Yuèzhī

Yǔ Gòng

Zhào

Zhōu cháo
司馬談

孫臏兵法

孫武

孫子兵法

鐵

吳

武帝

趙武靈王

乌孙

吳起

吳子

獫狁

新疆維吾爾自治區

匈奴

燕

月氏

禹貢

趙

周朝
Hàn court historian, author of the Shìji

Sun Bin's Art of War, a tactical treatise dated to the Warring States Period author of the Sūn Zì Bìngfă

The Art of War, a Warring States tactical treatise

'iron'

one of the states of the Spring and Autumn Period, situated in the South

an emperor of the Hàn dynasty, reigned c. 141-87 BCE

a king of the state of Zhào during the Warring States Period, $† 295$ BCE one of the nomadic peoples living in the steppes to the West of early China author of the $W u \dot{u} Z \grave{l}, \uparrow 361 \mathrm{BCE}$ a tactical treatise dated to the Warring States Period one of the semi-sedentary peoples living in close vicinity to the early Chinese the Uyghur Autonomous Province of Xīnjiāng, situated in the far West of China one of the nomadic peoples living in the steppes to the north of early China one of the Warring States, situated in the northeast at the borders to the steppes Tokharian-speaking nomads living in the Tarim Basin and the Héxī corridor, west of early China the "Tribute of Yu", part of the Shüjing one of the Warring States, situated in the north at the borders to the steppes the Zhou dynasty, c. 1046-256 BCE 